\title{
Deletion including the oligophrenin-1 gene associated with enlarged cerebral ventricles, cerebellar hypoplasia, seizures and ataxia
}

\author{
D Tentler ${ }^{1}$, P G ustavsson ${ }^{1}$, J Leisti ${ }^{2}$, M Schueler ${ }^{3}$, J Chelly ${ }^{4}$, E Timonen ${ }^{5}$, G A nnerén ${ }^{1}$, \\ HF Willard ${ }^{3}$ and N Dahl ${ }^{1}$ \\ ${ }^{1} D$ epartment of $G$ enetics and Pathology, U ppsala U niversity H ospital, U ppsala, Sweden \\ ${ }^{2} \mathrm{D}$ epartment of Clinical G enetics, O ulu U niversity H ospital, Finland \\ ${ }^{3}$ Center of H uman G enetics, Case Western Reserve U niversity School of M edicine, Cleveland, Ohio, USA \\ ${ }^{4}$ IN SE R M U-129-IG CM, Faculté de M édicine, Paris, France \\ ${ }^{5} \mathrm{D}$ epartment of Pediatrics, O ulu U niversity H ospital, Finland
}

\begin{abstract}
Non-specific $X$-linked mental retardation is a heterogeneous group of disorders with an incidence of approximately 1 in 500 males. A recently identified gene in X q12, encoding a R hoG TPase-activating protein, was found to be mutated in individuals with mental retardation. We describe here two sisters with a 46,XY karyotype and a microdeletion of the oligophrenin-1 gene and $1.1 \mathrm{M} \mathrm{b}$ of flanking D NA. We have characterised the molecular interval defining this microdeletion syndrome with the fibre-FISH technique. A visual physical map of $1.2 \mathrm{M} \mathrm{b}$ was constructed which spans the oligophrenin-1 gene and the androgen receptor gene. The analysis of the patients revealed a deletion which extended from the 5 end of the AR gene to a region approximately $80 \mathrm{~kb}$ proximal to the EPLG 2 gene. The clinical manifestations of the two sisters include psychomotor retardation, seizures, ataxia, hypotonia and complete androgen insensitivity. Cranial MRI scans show enlargement of the cerebral ventricles and cerebellar hypoplasia. 0 ur findings give further support for the involvement of the oligophrenin-1 gene in specific morphological abnormalities of the brain which is of importance in the investigation of male patients presenting with mental retardation. In combination with our results from physical mapping we suggest that a region around the oligophrenin-1 locus is relatively bereft of vital genes.
\end{abstract}

Keywords: oligophrenin-1 gene; mental retardation; deletion; X q12; fibre-FISH

\section{Introduction}

A large number of males has non-specific mental retardation which has been attributed to the existence

Correspondence: Dr Niklas Dahl, U nit of Clinical Genetics, D epartment of $G$ enetics and Pathology, U ppsala U niversity H ospital, S751 85 U ppsala, Sweden. Fax: +4618554025; E-mail: niklas.dahl@klingen.uu.se

Received 26 August 1998; revised 16 December 1998; accepted 7 J anuary 1999 of a number of genes on the $\mathrm{X}$-chromosome. The number of distinct genes behind this phenotype is unknown but it may be in the range of $10-50 .{ }^{1} \mathrm{~A}$ Ithough several genes involved in syndromic $X$-linked mental retardation have been identified, eg the fragile- $X$ syndrome, only three genes associated with non-specific mental retardation have been identified: the FMR2 gene, $^{2}$ the GDI 1 gene, ${ }^{3}$ and the oligophrenin-1 gene. ${ }^{4}$ The oligophrenin-1 gene was identified from the molecular characterisation of an $\mathrm{X}$-chromosomal 
breakpoint (X q12) in a female with mental retardation and an $X ; 12$ balanced translocation. ${ }^{5}$ The gene encodes a Rho-GTPase-activating protein which was found mutated in independent cases with non-specific $X$-linked mental retardation. Oligophrenin-1 is expressed in the developing neuroepithelium and is probably a regulator of R ho-G TPase targets. The R ho proteins are important mediators of intracellular signal transduction which affects cell migration and cell morphogenesis. ${ }^{6}$

We report on two sisters of Finnish descent with a normal 46,XY karyotype and with a distinct syndrome. The disease manifestations were similar in both sisters and include mental retardation, seizures, ataxia, hypotonia and complete androgen insensitivity syndrome (CAIS). A cranial MRI scan showed dilated cerebral ventricles and cerebellar abnormalities which resembled $\mathrm{D}$ andy-Walker malformations. The complex phenotype suggested a contiguous gene syndrome involving the AR gene in Xq11-q12 and one or several adjacent genes.

In our efforts to regionally map the deletion in this family, we used the fibre-FISH technique to generate a visual physical map with anchored clones on X q11-q12. $\mathrm{U}$ sing this map, spanning $1.2 \mathrm{Mb}$ of DNA previously unknown in size, we determined the extent of the deletion which includes the androgen receptor gene and the recently identified oligophrenin-1 gene. The molecular findings and the clinical features presented by the two sisters, including the abnormal MRI scan, are intriguing in light of the phenotype presented by the female with a balanced $X ; 12$ translocation which disrupts the oligophrenin-1 gene. ${ }^{5} \mathrm{O}$ ur results support the view that the oligophrenin-1 gene contributes to the cerebral and cerebellar malformations observed. This gene is a strong candidate in the investigation of males with unspecific mental retardation and similar intracranial abnormalities.

\section{Patients and Methods}

\section{Patients}

The family comprises parents and two daughters. The parents are healthy and there is no family history of mental retardation, neurological disorders or infertility. The elder sister presented with inguinal hernia shortly after birth and undescended testes were removed at the age of 1 year and 3 months. High resolution GTG banding was performed from peripheral blood cultures and her karyotype was shown to be $46, X Y$ without visible abnormalities of the $X$ chromosome. A t one year of age hypotonia was diagnosed and the EEG showed minor generalised background changes. Cranial M RI at age 3 years and 6 months showed a large cisterna magna with the left side being more severely affected. There were enlarged supratentorial ventricles, an enlarged fourth ventricle, hypoplastic cerebellar hemispheres and a hypoplastic vermis (Figure 1). Her psychomotor development has been delayed and at age 7, her developmental level corresponds to that of a child of two to two and a half years. She suffers from delayed development with regard to both motor and cognitive functions as well as speech. She also has epilepsy and aggressive behaviour. She shows a mild and generalised hypotonia and her gait is ataxic. A mild nystagmus is observed. She has impaired sensitivity to cold and to pain in the lower extremities.

The younger sister also presented with bilateral inguinal hernia. She showed a $46, X Y$ karyotype and testes were removed from the inguinal canals at the age of 3 months. The girl presented neonatally with motor attacks consisting of symmetric jerks of the extremities. The EEG was found to be normal and antiepileptic medication did not resolve the seizures. Cranial MRI showed that the third ventricle and the lateral ventricles were widened. A large symmetrical cystic cavity of the posterior fossa was observed with a connecting channel to the fourth ventricle which was of normal size. A t age 4 years, her psychomotor development is delayed but cognitive functions are close to normal. $\mathrm{N}$ eurological examination revealed generalised hypotonia and ataxia gait.

The mother was healthy and without history of developmental delay or neurological dysfunction. Her neurological status was normal upon clinical examination.

\section{Southern Blot Analysis}

Genomic DNA was isolated either directly from the blood samples obtained, or from established E pstein$B$ arr virus transformed lymphoblastoid cell lines, by use of a standard phenol-chloroform extraction method. ${ }^{7}$ Southern blotting and hybridisation were carried out essentially as described. ${ }^{8,9}$ Eight $\mu g$ of DNA was digested with E coRI or HindIII (Pharmacia, U ppsala, Sweden), separated on $1 \%$ agarose gel and transferred to $\mathrm{H}$ ybond-N plus (A mersham, B uckinghamshire, UK). Probes were labelled using Q uick prime (Pharmacia) and the probe was added to the prehybridisation 
A

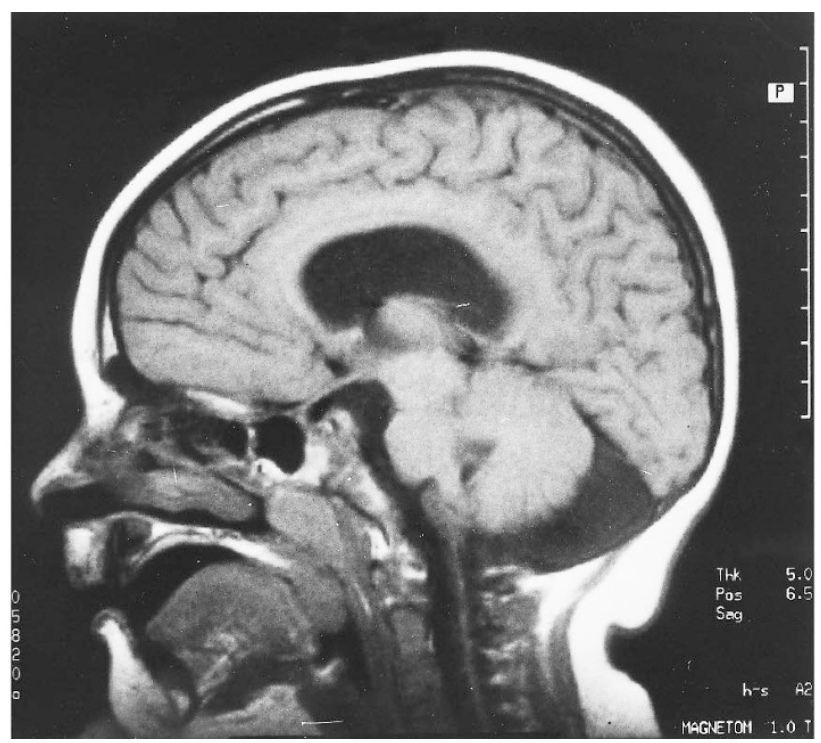

B

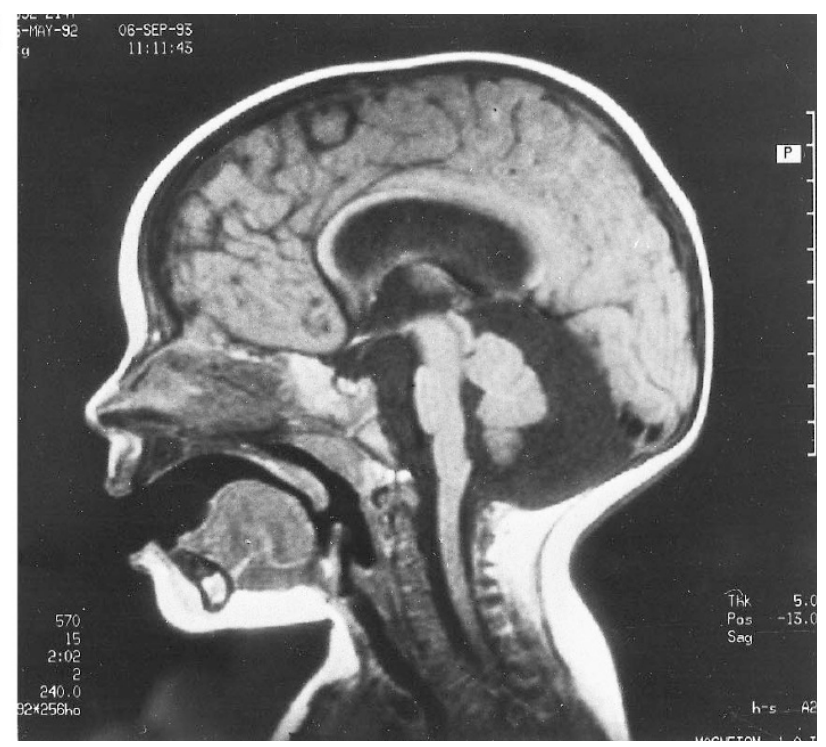

Figure 1 Cranial M RI scan of the two sisters a The elder sister at age 3 years and 6 months. b The younger sister at age 1 . B oth images show an enlarged cisterna magna and a cystlike formation of the posterior fossae

solution after 30-60 min. The hybridisation was carried out in the same solution. It was performed for $16-18 \mathrm{~h}$ at $42^{\circ} \mathrm{C}$. Blots were washed twice for $20 \mathrm{~min}$ in $2 \times \mathrm{SSC}, 0.1 \% \mathrm{SDS}$ at $65^{\circ} \mathrm{C}$, followed by a stringent wash in $0.5 \times \mathrm{SSC}, 0.1 \% \mathrm{SDS}$ in $15 \mathrm{~min}$ at $65^{\circ} \mathrm{C}$.

\section{DNA Probes and Primers for STS Analysis}

The following $X$ chromosome specific probes were used in this study to determine the extent of the deletion by Southern blot; p8 (DXS1), ${ }^{10}$ the AR CDNA, ${ }^{11}$ PGKP1, ${ }^{12}$ EPLG 2 CDNA ${ }^{13}$ and $D \times S 159,{ }^{14}$ and single copy subfragments of the cosmid 35 (positive for the oligophrenin-1 gene). The EPLG 2 CDNA was generated by $P C R$ directly from a human foetal CDNA library (Clontech, Palo A Ito, CA ) using primers from the CDNA sequence. Cosmid clones $2 \mathrm{C} 6$ and 35 were isolated from a cosmid library corresponding to YAC 4690. 4,15

The chromosome $X$-specific clones used for $\mathrm{FISH}$ were the P1 clone LCG -P1A R (positive for the 5 ' end of the AR gene), cosmid 1 (positive for the EPLG 2 gene), cosmid2C 6 (positive for the oligophrenin-1 gene), cosmid 21, cosmid 35, BAC1, BA C2 and BAC4. The cosmids 1 and 21 are derived from the ICRF human X-chromosome library. ${ }^{16}$ The BAC clones were isolated from the Research Genetics, Inc. bacterial artificial chromosome library and correspond to the following addresses: 177h17 (BAC1), 118l 24 (BAC2), and $312 \mathrm{c} 12$ (BA C4).
The relative order of the clones from the centromere to the telomere is: LCG -P1A R (containing the 5' UTR of the androgen receptor gene), $\mathrm{BAC2}, \mathrm{BAC} 1$, cosmid 21, BA C 4, cosmid 2C 6, cosmid 35 and cosmid 1 (M Schueler, HF Willard, personal communication 1997).

A mplicons for exons $B$ and $H$ of the $A R$ gene were generated by PCR using two sets of primers complementary to intronic sequences flanking the exons under the conditions described previously. ${ }^{17}$ The PCR was used in order to determine the deletion status of the two sisters, and also on control DNA. The PCR was carried out in a total volume of $50 \mu \mathrm{l}$ with $50 \mathrm{~mm} \mathrm{KCl}$, $1.5 \mathrm{mM} \mathrm{M} \mathrm{gCl}, 12.5 \mu \mathrm{g}$ bovine serum albumin $/ \mathrm{ml}$, $200 \mu \mathrm{m}$ of each dA TP, dCTP, dG TP, dTTP, $1 \mu \mathrm{m}$ of each primer and 0.035 units/ $\mu$ l A mpliTaq (Perkin-Elmer, Norvelle, CT) starting with $0.25 \mu \mathrm{g}$ genomic D NA. The $P C R$ conditions were denaturation at $94^{\circ} \mathrm{C}$ for $4 \mathrm{~min}$, followed by 30 cycles at $94^{\circ} \mathrm{C}$ for $1 \mathrm{~min}, 60^{\circ} \mathrm{C}$ for $1 \mathrm{~min}$, $72^{\circ} \mathrm{C}$ for $2 \mathrm{~min}$ and, after the last cycle, extension for another $7 \mathrm{~min}$ at $72^{\circ} \mathrm{C} ; 10 \mu \mathrm{l}$ of each reaction were analysed on a $2 \%$ agarose gel.

\section{FISH and Fibre-FISH Analysis}

Standard chromosome preparations were made from transformed lymphoblastoid cell lines for FISH to metaphase chromosomes. ${ }^{18}$ The probes used for metaphase FISH were LCG -P1AR, cosmid 2 C 6 , cosmid 35 and cosmid 1. 
FISH analysis on extended fibres was made essentially as described. ${ }^{19,20}$ Ficoll-separated lymphoblastoid cells derived from the patient and lymphoblastoid cells from a control individual were embedded in $1 \%$ low melting-point agarose at a concentration of $10^{7} \mathrm{cell} / \mathrm{s} / \mathrm{ml}$. A garose blocks were incubated at $+50^{\circ} \mathrm{C}$ in $2 \mathrm{mg} / \mathrm{ml}$ proteinase $\mathrm{K}$ and $1 \% \mathrm{~N}$-lauroylsarcosine in $50 \mathrm{~mm}$ EDTA for $48 \mathrm{~h}$. The blocks were washed several times in $1 \times \mathrm{TE}$ and stored at $+4^{\circ} \mathrm{C}$ in $50 \mathrm{~mm}$ EDTA.

A small piece of agarose embedded DNA was placed on a microscope slide, and $15 \mu$ l of water was added to the agarose block. To melt the agarose, the slide was heated on a heat block $\left(50 \mathrm{~s}, 100^{\circ} \mathrm{C}\right)$, and DNA was extended mechanically on a slide using the edge of another microscope slide. Extended DNA fibres were denatured using $0.8 \mathrm{M} \mathrm{NaCl} / 70 \% \mathrm{EtOH}$ at room temperature for $4 \mathrm{~min}$ followed by an ice-cold ethanolseries. Detection of the biotin-labelled probe was achieved by application of avidin-FITC, biotinylated anti-avidin (Vector labs) and finally avidin-FITC. The digoxigenin-labelled probe was detected using a mouse-derived monoclonal anti-digoxigenin (Sigma, St Louis, MI), anti-mouse Ig-digoxigenin (Boehringer $M$ annheim, $M$ annheim) and rhodamine-labelled antidigoxigenin. The slides were analysed with a Zeiss A xioskop epifluorescence microscope with a filter set for visualisation of rhodamine, FITC and DA PI fluorescence. Images were merged using a CCD camera (Photometrics) and the IPlab software (Vysis). The probe and inter-probe distances in kilobases were based on the known size of the inserts. The measurements were normalised and based on the signal lengths of two different probes in the same visual field in order to compensate optimally for the level of DNA stretching and variation in signal length. A minimum of 10 different fibres from different microscope fields were each measured for the estimation of distances.

\section{Analysis of $X$-inactivation Pattern}

The $X$-inactivation pattern was assessed for the methylation status of the PGK gene. ${ }^{21}$ The region encompassing a polymorphic $\mathrm{BstXI}$ site and a methylation sensitive $\mathrm{H}$ pall site was amplified by $P C R .{ }^{22}$ In a first step the PCR products were subjected to BstX I digestion and loaded on a $2 \%$ agarose gel to examine the presence for BstXI polymorphism. In a second analysis this procedure was also carried out after $\mathrm{H}$ pal I digestion (methylation sensitive) in order to amplify the same region of the inactive $X$ chromosome(s).

\section{Results}

Deletion Analysis of the Two Sisters

The two sisters were previously uncharacterised at the molecular level. The initial analysis involved PCR of exons $B$ and $H$ in the $A R$ gene. No resulting amplicons were detected in the two sisters which suggested that the exons were deleted. The entire AR CDNA (corresponding to $\mathrm{nt}-530$ to 1170 of the protein coding region) was then used as a probe for hybridisation and one distinct and rearranged band was detected in both sisters (not shown). The more centromeric probe p8 (DXS1) gave normal hybridisation signals in the patient DNA . The more telomeric probe corresponding to the PGKP1 gene did not show any hybridisation signals. H owever, the ELPG 2 gene and DXS159 which are localised telomeric of PGKP1, were shown to be present. The results indicate a deletion extending from the $5^{\prime}$ region of the $A R$ gene to a region between PGKP1 and ELPG2. Single copy subfragments of cosmid 35 were hybridised to filters with DNA of the sisters and normal individuals. No hybridisation signals were observed with the subclones from cosmid 35 on DNA from the two sisters (Figure 2).

\section{Fibre-FISH Map of the Xq11-q12 Region}

In order to visually map the distances between the clones within and flanking the deletion we used unfixed linearised DNA fibres from healthy females on microscope slides. Figure 3 shows the order and the localisation of three BACs, four cosmids and one P1 clone based both on the fibre FISH results and on an STSbased physical contig of the region (M Schueler, HF Willard, personal communications 1997). The individual clone sizes were determined by restriction enzyme digestion. The hybridisation to fibres was performed with at least three probes for the determination of the order of clones. To assure the location and distance from other probes, each probe was used in different combinations with other probes. Two to five different hybridisations were performed per combinations of clones. To evaluate the extent of DNA stretching and its variability, the signals of each clone were measured from the slides. The results of the measurements of individual clones and of inter-clone distances were uniform at distances $<200 \mathrm{~kb}$. B ut the variation between individual measurements became greater when the distance was $>200 \mathrm{~kb}$. The order of clones determined by fibre-FISH was: X qcen-L CG P1A R-BA C 2-BA C 1-cosmid 21-BA C 4cosmid 35-cosmid 2C 6-cosmid 1 (Figure $3 a$ ). Some of 


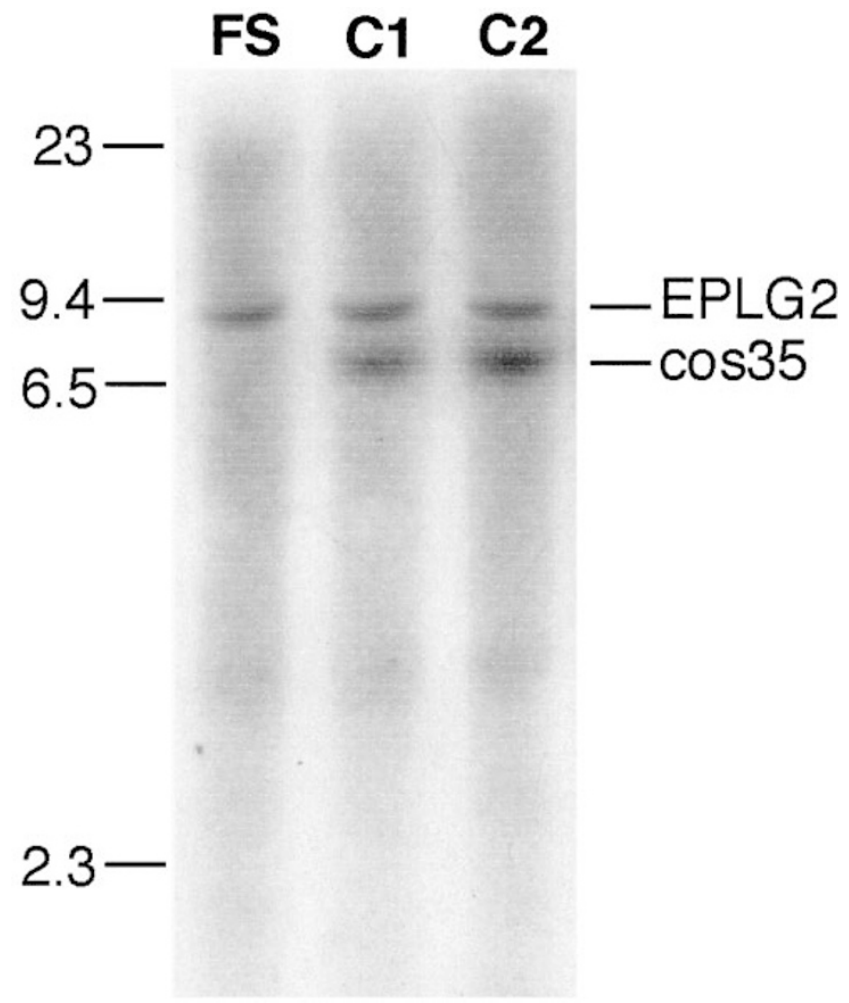

Figure 2 Southern blot analysis with a 1-kb end-fragment derived from cosmid 35. The entire cosmid is located within the oligophrenin-1 gene. ${ }^{4}$ The EPL G 2 cD NA was co-hybridised and used as a control probe. Peripheral lymphocyte D NA was digested with EcoRI. No hybridising band is seen for the cosmid 35 derived probe from the proband FS. A normal signal is seen in DNA from healthy control individuals ( $C 1$ and C2)

the clones overlapped including BAC2, BAC1 and cosmid 21 , and cosmid 35 and cosmid $2 C 6$, respectively. $B$ ased on measurements from different combinations of probes, the total distance between the flanking clones LCG-A RP1 and cosmid 1 was estimated to be approximately $1.2 \mathrm{M} \mathrm{b}$.

\section{Fibre-FISH Analysis on the Patients}

$\mathrm{FISH}$ analysis to metaphase chromosomes revealed no hybridisation signals for cosmids $2 \mathrm{C} 6,21$ and 35 , whereas the cosmid 1 and LCG-P1AR gave normal signal patterns (not shown). Fibre-FISH analysis was carried out on extended DNA from both sisters. The combined results from metaphase $\mathrm{FISH}$ analysis and Southern blot analysis on DNA from the patients suggested that the deletion included cosmids $2 \mathrm{C} 6,21$ and 35 but not cosmid 1. Fibre-FISH hybridisation revealed that the LCG-PIA R clone, which contains the $5^{\prime}$ extremity of the AR gene, gave a signal of normal length on fibres from the two sisters. This suggests that the centromeric deletion breakpoint is located very close to the end of the P1 clone and in the $5^{\prime}$ end of the AR gene. The three BA Cs and the cosmids $2 C 6,21$ and 35 gave no hybridisation signals on the extended DNA. H owever, the more telomeric cosmid 1, containing part of the ELPG2 gene, showed a normal signal (Figure $3 b)$. Co-hybridisation of the LCG-PIAR clone and cosmid 1 revealed signals within the same visual field. The estimates of distance between clones were based on the measurements of clone size and the length of individual hybridisation signals as for the construction of the visual physical map. The inter-clone distance between the LCG-PIAR clone and cosmid 1 was estimated to be $80 \mathrm{~kb}$ and the distance estimate was consistent in the two sisters. Thus, the distance between the LCG-PIA R clone and cosmid 1 was shortened by $1120 \mathrm{~kb}$, or approximately $1.1 \mathrm{M} \mathrm{b}$, when compared with normal fibres.

\section{$X$-inactivation Pattern}

The results are shown in Figure 4. Examination of the $B$ stXI polymorphism in the PGK gene showed that the mother was heterozygous for the $B$ stX I recognition site. A fter $\mathrm{H}$ pall digestion and amplification with $P C R$, the BstXI polymorphism revealed that both the 433-bp band and the 530-bp band were of equal intensity. The results indicated a random $X$-inactivation in leukocytes of the mother. The 530-band of the father and the daughter, representing the single active $\mathrm{X}$-chromosome, disappeared after $\mathrm{H}$ pall digestion.

\section{Discussion}

We have shown that two $46, X Y$ sisters with enlarged cerebral ventricles, cerebellar anomalies, mental retardation, seizures, ataxia, mental retardation and CAIS carry a $1.1 \mathrm{Mb}$ microdeletion in Xq11-q12. The centromeric deletion breakpoint is located in the $5^{\prime}$ end of the A R gene and we define the telomeric breakpoint as located between the oligophrenin-1 gene, which is included in the deletion, and the EPLG 2 gene. To map the physical distances of the region telomeric to the $A R$ gene we initiated the construction of a visual map with available genomic clones and the fibre-FISH method. No accurate distances are available from the $A R$ gene to the EPLG 2 gene and the technique enabled us to measure the size of the deletion. With the complete visual physical map as reference, the size of the deletion 
(a)
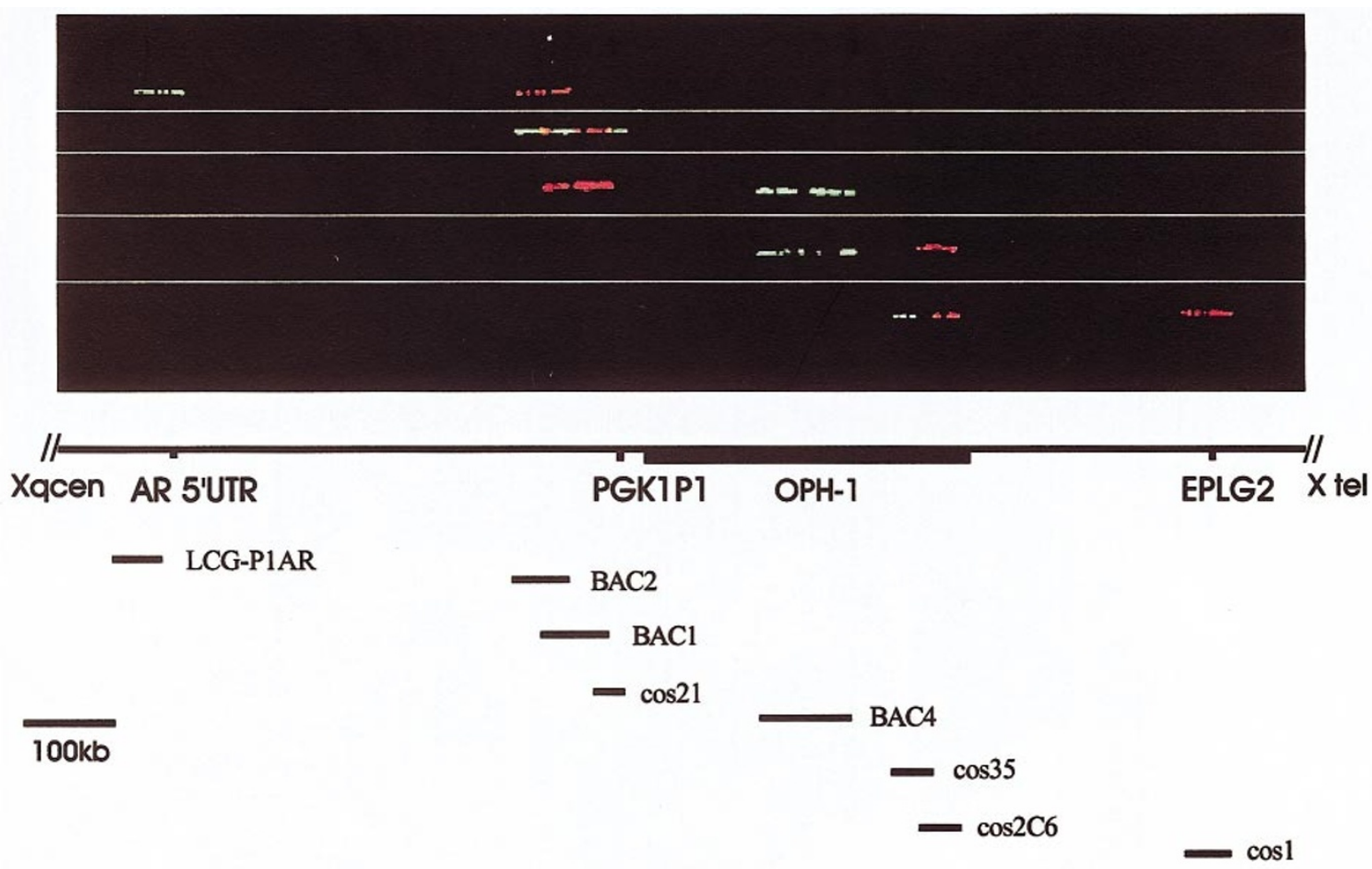

(b)
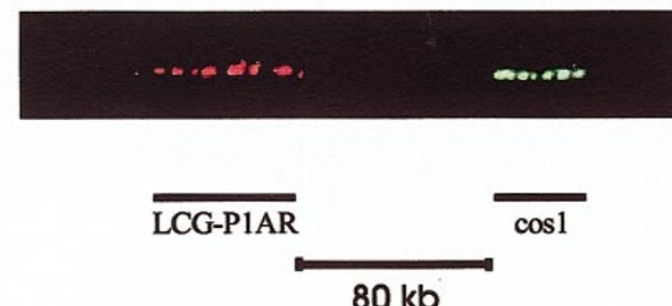

Figure 3 Physical mapping of $X$ q12 by fiber-FISH . a C onstruction of a high resolution map with eight anchored clones from the $\mathrm{P} 1$ clone L CG -P IA R (contains the $5^{\prime}$ extremity of the AR gene) to cosmid 1 (contains part of E PLG 2). The distance between the two clones is estimated to be $1.2 \mathrm{Mb}$ on fibres from normal individuals. Examples of fibres shown represent a selection of experiments performed in the map construction. E ach of the mapping results was confirmed by hybridisations of different probe combinations. BAC2 (green), BAC1 (red) and cosmid 21 (green) overlap. Similarly, cosmid 35 (green) and cosmid 2C 6 (red) overlap. The approximate extent of the oligophrenin-1 gene is indicated $(\mathrm{OPH}-1)$. b Visualisation of the deletion in one of the two sisters. The distance between the P 1 clone L CG -ARP 1 and cosmid 1 is reduced to approximately $80 \mathrm{~kb}$.

was directly measured by FISH analysis to extended fibres from the patients.

Previous reports have shown that mutations in the oligophrenin-1 gene are associated with $M R$, and a female with disruption of the oligophrenin-1 gene presents with dilated ventricles, cerebellar atrophy, mental retardation and seizures. ${ }^{5}$ With the exception of CAIS, this female's clinical presentation shows a considerable overlap with the features observed in our two cases. From the size of the deleted region it is possible that genes, in addition to the AR gene, the pseudogene PGKP1 and the gene for oligophrenin-1, 

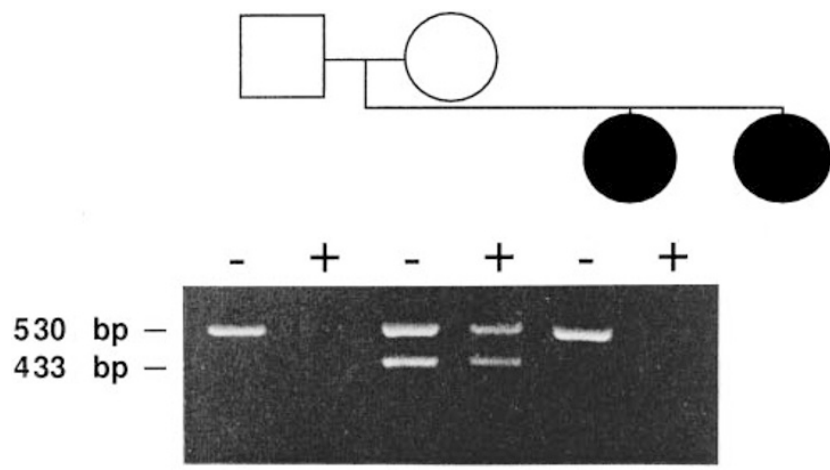

Figure $4 X$-inactivation analysis in the father, mother and one of the two $46, X Y$ daughters. A $530 \mathrm{bp}$ fragment of the PGK gene around a polymorphic BstXI site and a methylation sensitive $\mathrm{H}$ pall site was amplified by $\mathrm{PCR}{ }^{21,22}$ A mplicons generated from genomic were digested by B stXI (-). The same procedure was also carried out after digestion with $\mathrm{H}$ pall $(+)$ which results in amplicons derived from the inactive $X$-chromosome. The mother is heterozygous for the polymorphism (530-bp and 433-bp bands, respectively). The experiment was repeated after $\mathrm{H}$ pall digestion and revealed an apparent random $\mathrm{X}$-inactivation pattern. No bands corresponding to an inactive $\mathrm{X}$-chromosome are seen in the hemizygous father and the proband, respectively

are encoded therein. However, no indications of such genes were found from the clinical presentation in our patients when compared with the features of the female with a $t(X ; 12)$.

The clinical findings that focused our attention on the two sisters were the enlargement of cerebral ventricles and the cerebellar anomalies detected by cranial MRI. The clinical and molecular findings in our two cases and the previously reported female with $t(X ; 12)$ suggest that oligophrenin-1 may be implicated in the formation of the brain and its cavities. This hypothesis is supported by functional analysis of the oligophrenin-1 gene product as a R ho-G TPase-activating protein and its expression in the developing brain. ${ }^{4}$ The $\mathrm{R}$ ho family of proteins has been shown to mediate neuronal cell migration and cellular morphogenesis., ${ }^{3,6,23}$

Two subjects with $M R$ and CAIS resulting from a complete deletion of the $A R$ gene and flanking DNA have previously been reported. ${ }^{24,25} \mathrm{O}$ ne of these mentally retarded patients, A R $\Delta 2,{ }^{24}$ presented with convulsive disorder and hyperactive behaviour. The presence of epilepsy in addition to M R is noteworthy since this is also observed in our two cases and in the female with a $t(X ; 12)$ and a disruption of the oligophrenin-1 gene. The other previously reported subject with CA IS and mental retardation, $A R \Delta 3,{ }^{25}$ presents with mild mental retardation and mild dysmorphic features. 0 ur visual physical map with anchoraged markers suggests that the deletions in both $A R \Delta 2$ and $A R \Delta 3$ may include at least part of the oligophrenin-1 gene.

The PCR analysis of the PGK gene in the mother showed bands representing the two $\mathrm{X}$-chromosomes of equal intensity after $\mathrm{H}$ pall digestion. This implies that the $\mathrm{X}$ inactivation pattern is random in the otherwise healthy mother. However, from our analysis it is not certain whether the deletion is present in leukocytes of the mother.

The present study has shown that an X-linked syndrome, including dilated ventricles, cerebellar malformations, seizures, ataxia and mental retardation, is associated with a $1.1 \mathrm{Mb}$ deletion including the oligophrenin-1 gene. 0 ur findings support the proposal that mutations in the oligophrenin-1 gene are associated with morphological abnormalities of the brain including enlargement of the brain ventricles and cerebellar hypoplasia. Since the affected family members show no major associated symptoms except CAIS, the deleted region can be expected to be relatively bereft of (vital) genes.

The visual physical mapping in this study has added important information about size estimates over the region from the $A R$ gene to $E P L G 2$. In combination, our clinical and molecular observations provide important information for the future identification of patients with $M R$ caused by mutations in the oligophrenin-1 gene.

\section{Acknowledgements}

We thank B Carlsson for technical assistance, O P K alloniemi for the gift of the probe LCG-P1AR, and A Palotie and $F$ Parente for technical advice. This study was supported from the Swedish Medical Research Council (to NDahl), The Sävstaholm Society (to D Tentler), the $T$ and R Söderberg Foundation, the Ronald $\mathrm{MCD}$ onald Fund for Children, B orströms Foundation, the L undberg Foundation, and grant HD 26202 from the NIH (to H Lubs, C Schwartz, and HF Willard).

\section{References}

1 G edeon A K, D onnelly A J, M ulley J C, Kerr B, Turner G : $\mathrm{H}$ ow many $X$-linked genes for non-specific mental retardation (MRX) are there? Am J Med Genet 1996; 64: 158-162.

2 Gecz J, Gedeon A K, Sutherland GR, M ulley J C: Identification of the gene FMR2, associated with FRAXE mental retardation. $N$ at $G$ enet 1996; 3: 105-108.

3 D'A damo P, M enegon A, Lo Nigro C et al: Mutations in GDII are responsible for $X$-linked non-specific mental retardation. N at G enet 1998; 19: 134-139. 
4 Billuart $\mathrm{P}$, Bienvenu $\mathrm{T}, \mathrm{R}$ once $\mathrm{N}$ et al: Oligophrenin-1 encodes a rhoGA $P$ protein involved in $X$-linked mental retardation. N ature 1998; 392: 923-926.

5 Bienvenu T, D er-Sarkissian H, Billuart $P$ et al: $M$ apping of the $X$-breakpoint involved in a balanced $X ; 12$ translocation in a female with mild mental retardation. $\mathrm{E}$ ur J H um Genet 1997; 5: 105-109.

6 Zipkin ID, K indt RM, Kenyon CJ: Role of a new R ho family member in cell migration and axon guidance in $C$. elegans. Cell 1997; 90: 883-894.

7 Sambrook J, Fritsch E, M aniatis T: Molecular cloning: A laboratory manual. Cold Spring $\mathrm{H}$ arbor L aboratory $\mathrm{M}$ anual. Cold Spring Harbor Laboratory Press: New York, 1989.

8 Oberlé I, Camerino G, K loepfer $C$ et al: Characterisation of a set of $X$-linked sequences and of a panel of somatic cell hybrids useful for the regional mapping of the human $X$ chromosome. H um G enet 1986; 72: 43-49.

9 Dahl N, Goonewardena P, Malmgren $\mathrm{H}$ et al: Linkage analysis of families with fragile $X$ mental retardation, using a novel R FL P marker (DX S304). A m J H um G enet 1989; 45: 304-309.

10 Lafreniere RG, Brown CJ, Powers VE et al: Physical mapping of $60 \mathrm{DNA}$ markers in the p21.1-q21.3 region of the human X chromosome. Genomics 1991; 11: 352-363.

11 L ubahn D B, Joseph D R, Sullivan PM, Willard H F, French $\mathrm{FS}$, Wilson EM: Cloning of human androgen receptor complementary DNA and localization to the $\mathrm{X}$ chromosome. Science 1988; 240: 237-330.

12 Willard HF, G oss SJ, H olmes MT, M unroe D L: R egional localization of the phosphoglycerate kinase gene and pseudogene on the human $X$ chromosome and assignment of a related DNA sequence to chromosome 19. Hum G enet 1985; 71: 138-143.

13 Fletcher FA, Carpenter M K, Shilling $\mathrm{H}$ et al: LER K-2, a binding protein for the receptor-tyrosine kinase $E L K$, is evolutionarily conserved and expressed in a developmentally regulated pattern. O ncogene 1994; 9: 3241-3247.

$14 \mathrm{H}$ ofker $\mathrm{MH}$, Bergen A A, Skraastad MI et al: Efficient isolation of $X$ chromosome-specific single-copy probes from a cosmid library of a human X/hamster hybrid-cell line: mapping of new probes close to the locus for $X$-linked mental retardation. A m J H um G enet 1987; 40: 312-328.
15 Fletcher FA, H uebner K, Shaffer LG et al: A ssignment of the gene ( $E P L G 2$ ) encoding a high-affinity binding protein for the receptor tyrosine kinase elk to a 200-kilobasepair region in human chromosome $\mathrm{X}$ q12. G enomics 1995; 25: 334-335.

16 Nizetic $D$, Z ehetner $G$, M onaco A P, G ellen L, Y oung BD, Lehrach $\mathrm{H}$ : Construction, arraying and high-density screening of large insert libraries of human chromosomes $X$ and 21: their potential use as reference libraries. Proc Natl A cad Sci USA 1992; 88: 3233-3237.

17 L ubahn D B, B rown TR, Simental JA et al: Sequence of the intron/exon junctions of the coding region of the human androgen receptor gene and identification of a point mutation in a family with complete androgen insensitivity. Proc Natl A cad Sci USA 1989; 86: 9534-9538.

18 G ustavsson P, Skeppner G, Johansson B et al: Diamond$B$ lackfan anemia in a girl with an $X ; 19$ balanced reciprocal translocation. J Med G enet 1997; 34: 779-782.

19 Heiskanen M, Karhu R, H ellsten E, Peltonen L, K allioniemi OP, Palotie A: High resolution mapping using fluorescence in situ hybridization to extended D NA fibers prepared from agarose-embedded cells. BioTechniques 1994; 17: 928-933.

20 Heiskanen $M, H$ ellsten $E$, Kallioniemi OP et al: Visual mapping by fiber-FISH. G enomics 1995; 30: 31-36.

21 G illiland D G, B lanchard K L, Levy J, Perrin S, B unn HF: Clonality in myeloproliferative disorders: analysis by means of the polymerase chain reaction. Proc Natl A cad Sci USA 1991; 88: 6848-6852.

22 O gata T, Wakui $\mathrm{K}, \mathrm{M}$ uroya $\mathrm{K}$ et al: $\mathrm{M}$ icrophthalmia with linear skin defects syndrome in a mosaic female infant with monosomy for the $X \mathrm{p} 22$ region: molecular analysis of the X p22 breakpoint and the $X$-inactivation pattern. $\mathrm{H}$ um G enet 1998; 103: 51-56.

23 L uo L, H ensch TK, A ckerman L, B arbel S, Jan LY, Jan $Y N$ : D ifferential effects of the Rac GTPase on Purkinje cell axons and dendritic trunks and spines. Nature 1996; 379: $837-840$

24 Trifiro M, Gottlieb B, Pinsky L et al: The $56 / 58 \mathrm{kD}$ a androgen-binding protein in male genital skin fibroblasts with a deleted androgen receptor gene. $\mathrm{M}$ ol C ell E ndocrinol 1991; 75: 37-47.

25 Davies HR, Hughes IA, Savage MO et al: A ndrogen insensitivity with mental retardation: a contiguous gene syndrome. J M ed G enet 1997; 34: 158-160. 